OPEN ACCESS

Edited by:

Pierrette Gaudreau,

Université de Montréal, Canada

Reviewed by:

Denis Richard,

Laval University, Canada

M. Foster Olive,

Arizona State University, USA

*Correspondence:

Isabel M. H. Quadros

isabel.quadros@unifesp.br

Specialty section:

This article was submitted to Neuroendocrine Science,

a section of the journal

Frontiers in Endocrinology

Received: 15 June 2016 Accepted: 20 September 2016

Published: 18 October 2016

Citation:

Kawakami SE, Quadros IMH and

Suchecki D (2016) Naltrexone Prevents in Males and Attenuates in Females the Expression of Behavioral Sensitization to Ethanol Regardless of Maternal Separation.

Front. Endocrinol. 7:135.

doi: 10.3389/fendo.2016.00135

\section{Naltrexone Prevents in Males and Attenuates in Females the Expression of Behavioral Sensitization to Ethanol Regardless of Maternal Separation}

\author{
Suzi E. Kawakami, Isabel M. H. Quadros* and Deborah Suchecki
}

Department of Psychobiology, Escola Paulista de Medicina - Universidade Federal de São Paulo (UNIFESP), Sao Paulo, Sao Paulo, Brazil

Maternal separation alters the activity of the opioid system, which modulates ethanolinduced stimulation and behavioral sensitization. This study examined the effects of an opioid antagonist, naltrexone (NTX), on the expression of behavioral sensitization to ethanol in adult male and female mice submitted to maternal separation from postnatal days (PNDs) 2 to 14. Whole litters of Swiss mice were either not separated [animal facility rearing (AFR)] or separated from their mothers for $3 \mathrm{~h}$ [long maternal separation (LMS)]. Starting on PND 90, male and female AFR and LMS mice received daily i.p. injections of saline (SAL) or ethanol $(\mathrm{EtOH}, 2.2 \mathrm{~g} / \mathrm{kg})$ for 21 days. Locomotor activity was assessed in cages containing photoelectric beams, once a week, to examine the development of behavioral sensitization. Five days after the end of the chronic treatment, animals were submitted to four locomotor activity tests spaced by $48 \mathrm{~h}$, to assess the expression of behavioral sensitization. In all tests, animals received two i.p. injections with a 30-min interval and were then assessed for locomotor response to different treatment challenges, which were: SAL/SAL, SAL/EtOH $(2.2 \mathrm{~g} / \mathrm{kg})$, NTX $2.0 \mathrm{mg} / \mathrm{kg}$ (NTX2)/EtOH, and NTX $4.0 \mathrm{mg} / \mathrm{kg}$ (NTX4)/EtOH. Regardless of maternal separation, $\mathrm{EtOH}$-treated male and female mice displayed increased locomotor responses to $\mathrm{EtOH}$ during the 21-day treatment, indicating the development of behavioral sensitization. In the SAL/EtOH challenge, EtOH-treated LMS and AFR male and female mice exhibited higher locomotor activity than their SAL-treated counterparts, indicating the expression of sensitization. The coadministration of either dose of NTX blocked the expression of locomotor sensitization in both AFR and LMS male mice with a history of EtOH sensitization. In females, a significant attenuation of $\mathrm{EtOH}$ sensitization was promoted by both NTX doses, while still maintaining an augmented stimulant response to $\mathrm{EtOH}$. Importantly, maternal separation did not interfere in this phenomenon. These results indicate that expression of behavioral sensitization was importantly modulated by opioidergic mechanisms both in male and female mice and that maternal separation did not play a major role in either development or expression of this $\mathrm{EtOH}$ sensitization.

Keywords: neonatal stress, locomotor sensitization, opioid system, alcohol 


\section{INTRODUCTION}

Maternal care is essential for the proper development of altricial mammals, whose central nervous system maturation takes place postnatally. The ontogenesis of the hypothalamic-pituitary-adrenal (HPA) axis stress response also occurs during the first weeks of life in mice and rats and is regulated by maternal presence, which tonically inhibits its activation by most stressors. Maternal care is responsible for maintaining the pups' HPA axis quiescent; specifically stroking of the anogenital area inhibits the ACTH stress response, whereas lactation reduces corticosterone secretion (1-5). This inhibition is demonstrated by separating the offspring from its mother for periods of $8-24 \mathrm{~h}$, resulting in elevated stress-induced ACTH and corticosterone stress responses $(2,4,6-8)$.

Disruption of the mother-infant relationship produces longterm alterations in numerous behaviors and brain systems (9), including vulnerability to drug abuse (10) and changes in the activity of the opioid system (11). A considerable number of studies have shown that separation of pups from their mothers for long periods of time during the first 2 weeks of life [3-6 h/ day; hereby referred to as long maternal separation (LMS)] affects brain opioid levels (12-15). Increases in immunoreactivity for Met-enkephalin peptides are detected in regions associated with reward and emotional behaviors, including the medial prefrontal cortex $(12,13)$, while less consistent changes are found in dynorphin-B levels, depending on the brain region and separation protocol (11). Additionally, LMS animals show greater sensitivity to morphine, an opioid agonist (16), compared to control animals. Changes in the opioid system are particularly relevant within the context of drug abuse, since these neuropeptides are involved in motivation and reward, regulating the activity of the dopaminergic mesolimbic system by means of $\mu-, \delta$-, and $\kappa$-opioid receptors (17-19). However, the effects of LMS on drug addiction-related behaviors appear to be sexually dimorphic for it increases self-administration of psychostimulants (10), morphine (20), and ethanol in males (21-24), but not in females $(13,25)$. LMS also modifies behavioral sensitization to cocaine (26) and ethanol in females, but not in males (27), indicating a strong influence of sex and paradigm used to evaluate the neurobiological aspects involved in drug addiction.

Locomotor sensitization is defined as an augmented behavioral response, e.g., locomotor activity, to the stimulant effects of drugs upon repeated administration. This paradigm has been used to study neuroadaptive changes induced by chronic EtOH administration, which may contribute to $\mathrm{EtOH}$ addiction. Interestingly, opioids seem to play a key role in the motivational aspects of drug and alcohol abuse in several animal models, including behavioral sensitization [for reviews, see Ref. $(28,29)$ ]. Non-selective opioid receptors antagonists, such as naltrexone (NTX) or naloxone, decrease EtOH-induced stimulant effect $(30,31)$ and inhibit the development of behavioral sensitization to ethanol $(32,33)$. However, the expression of behavioral sensitization to EtOH is not affected by these opioid receptor antagonists $(32,34)$. In the present study, we evaluated the effect of NTX, a non-selective opioid antagonist of important clinical value in the treatment of alcohol dependence [for reviews, see Ref. $(18,35)]$, on the expression of behavioral sensitization to ethanol in maternally separated adult mice. For this, we employed higher NTX doses than previous studies (32), and also tested both male and female mice to investigate possible sex differences [as opposed to only testing males, as in Ref. (32-34)]. Additionally, we tested the effect of an early life stress manipulation, which could further modulate the expression of ethanol sensitization $(26,27)$ and the sensitivity to NTX effects (11-16).

\section{MATERIALS AND METHODS}

\section{Animals}

Swiss mice were mated in the animal facility of the Department of Psychobiology and daily inspected for the presence of pups. The day of the birth was designated postnatal day (PND) 0. On PND 1, litters were culled to 5 males and 5 females. Animals were maintained in a controlled 12-h light-dark cycle (lights on at 7:00 a.m. and off at 7:00 p.m.) and temperature $\left(23 \pm 2^{\circ} \mathrm{C}\right)$. Food and water were provided ad libitum throughout the entire study. Animal manipulations and protocols were approved by the Ethics Committee in Research (CEP\# 521/07), and the experiments were carried out in accordance with Brazilian regulations on the use and care of animals.

\section{Neonatal Manipulations}

From PND 2 to 14, pups were subjected to daily maternal separation for $180 \mathrm{~min}$ (LMS) or not separated until weaning on PND 22 [animal facility rearing (AFR)]. In the LMS group, whole litters were removed from the nest, at $~ 12: 00$ hours, and placed in separate cages on a heating pad set at $33^{\circ} \mathrm{C}$, whereas the mothers remained in the home cage and, at the end of the allotted period, litter and mother were reunited in the home cage. Once a week during the separation, half of the old bedding material was mixed with clean material, in order to prevent excessive ammonia accumulation and still keeping olfactory familiarity from the old bedding material. AFR litters were handled during cage cleaning (three times a week). Weaning took place on PND 22 and two to three litters from the same group were housed in plastic cages (10-15 animals).

\section{Drugs}

Ethanol (Synth) was prepared fresh every day, in a concentration of $15 \% \mathrm{w} / \mathrm{v}$, in $0.9 \%$ saline (SAL) and administered at a dose of $2.2 \mathrm{~g} / \mathrm{kg}$ (i.p.). The opioid antagonist, NTX (Sigma-Aldrich) was also prepared before use, in $0.9 \% \mathrm{SAL}$, and the doses were chosen based on a previous study (33).

\section{Behavioral Sensitization Habituation (Hab)}

At PND 90, AFR and LMS male and female mice (8-9 litters/ manipulation) were individually tested in Opto-Varimex activity cages (Columbus Instruments, Columbus, OH, USA), which detect locomotion by interruptions of horizontal photoeletric beams, for $15 \mathrm{~min}$. 


\section{Development Phase}

Fourty-eight hours after the habituation test, the animals were allocated into two treatment groups, and received daily injections of SAL or $2.2 \mathrm{~g} / \mathrm{kg} \mathrm{EtOH}$, i.p, for 21 days $(n=10-13$ animals/ sex/group), since studies from our lab have shown that this treatment induces consistent levels of behavioral sensitization $(36,37)$ (Figure 1). Locomotor activity was measured once a week (days $1,7,14$, and 21 of treatment), immediately after the treatment, for $15 \mathrm{~min}$.

\section{Expression Phase}

Five days after the last administration of the development/ induction phase, animals were submitted to 4 challenges spaced by $48 \mathrm{~h}$. In all challenges, animals received two i.p. injections spaced by $30 \mathrm{~min}$ (Figure 1). All mice were submitted to drug challenges in the following order: SAL/SAL, SAL/EtOH $(2.2 \mathrm{~g} / \mathrm{kg})$, NTX $(2.0 \mathrm{mg} / \mathrm{kg}) / \mathrm{EtOH}(2.2 \mathrm{~g} / \mathrm{kg})$, and (NTX, $4.0 \mathrm{mg} / \mathrm{kg}) / \mathrm{EtOH}$ $(2.2 \mathrm{~g} / \mathrm{kg})$. Immediately after the second administration, the animals were placed in the activity cages, and locomotor activity was measured for $15 \mathrm{~min}$. All procedures were carried out in the afternoon (between 12:00 and 17:00 hours).

\section{Statistical Analysis}

Locomotor response to habituation was compared between groups (AFR, LMS) by Student's $t$-test. The locomotor response during the development phase was analyzed by three-way analysis of variance (ANOVA) with group (AFR, LMS), treatment (SAL, $\mathrm{EtOH}$ ), and day (repeated measure) as main factors. During the expression phase, the locomotor response was analyzed by a three-way ANOVA for repeated measures, with group (AFR, LMS), pretreatment (SAL, EtOH), and challenge as the repeated measure (Sal/Sal, Sal/EtOH, NTX2/EtOH, and NTX4/EtOH). Males and females were analyzed separately. When appropriate, post hoc analysis was carried out using Newman-Keuls test, with the level of significance set as $p \leq 0.05$.

\section{RESULTS}

\section{Habituation}

Pairwise comparison showed no differences in locomotion between LMS and AFR in either male $\left[t_{(46)}=0.31 ; p>0.05\right]$ or female mice $\left[t_{(47)}=1.51 ; p>0.05\right]$ (Table 1).

\section{Development of Behavioral Sensitization Male Mice}

ANOVA revealed main effects of treatment $\left[F_{(1,44)}=25.41\right.$, $p<0.01]$ and day $\left[F_{(3,132)}=4.36, p<0.01\right]$ and an interaction between treatment and day $\left[F_{(3,132)}=10.32, p<0.01\right]$, with no differences between AFR and LMS manipulations (Figure 2). Newman-Keuls tests for the treatment $x$ day interaction showed that $\mathrm{EtOH}$-treated mice presented increases in locomotor activity on test days 7,14 , and 21 , relative to SAL-treated animals $(p<0.05)$. EtOH-induced hyperactivity was also higher on days 14 and 21, when compared to responses to EtOH on days 1 and $7(p<0.01)$.

\section{Female Mice}

ANOVA revealed main effects of treatment $\left[F_{(1,45)}=45.80\right.$, $p<0.01]$ and day $\left[F_{(3,135)}=28.01, p<0.01\right]$ and interaction between these factors $\left[F_{(3,135)}=22.85, p<0.01\right]$, with no group

TABLE 1 | Locomotor activity (counts), during habituation, of male and female mice kept with their mothers for the entire developmental period [animal facility rearing (AFR)] or submitted to long maternal separation (LMS), from postnatal days 2 to 14 .

\begin{tabular}{ccc}
\hline & Males & Females \\
\hline AFR & $1209.57 \pm 369.82(23)$ & $1573.75 \pm 523.22(24)$ \\
LMS & $1183.04 \pm 212.20(25)$ & $1375.68 \pm 387.89(25)$
\end{tabular}

The values are presented as mean $\pm S D$. Number of animals/group is shown in parenthesis.

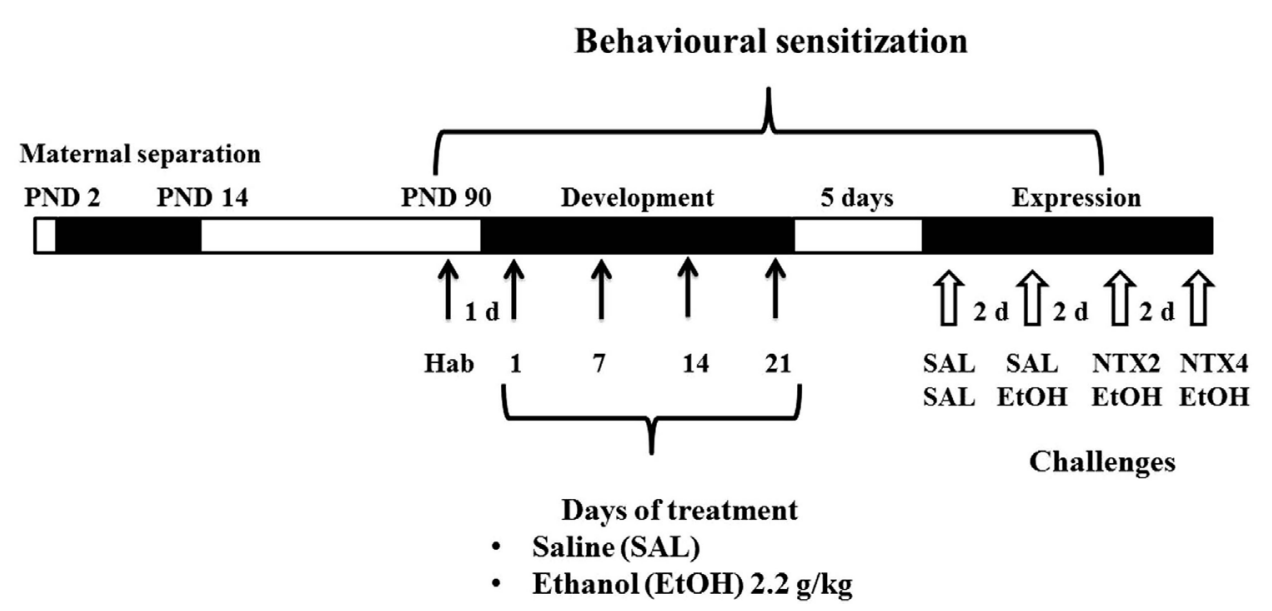

FIGURE 1 | Schematic representation of the experimental design. Black horizontal bars represent daily saline (SAL) or ethanol (EtOH) i.p. administration. The numbers represent the locomotor activity tests. White arrows represent two i.p. administrations, first with SAL or NTX (2.0 or $4.0 \mathrm{mg} / \mathrm{kg})$ and second with SAL or EtOH. 

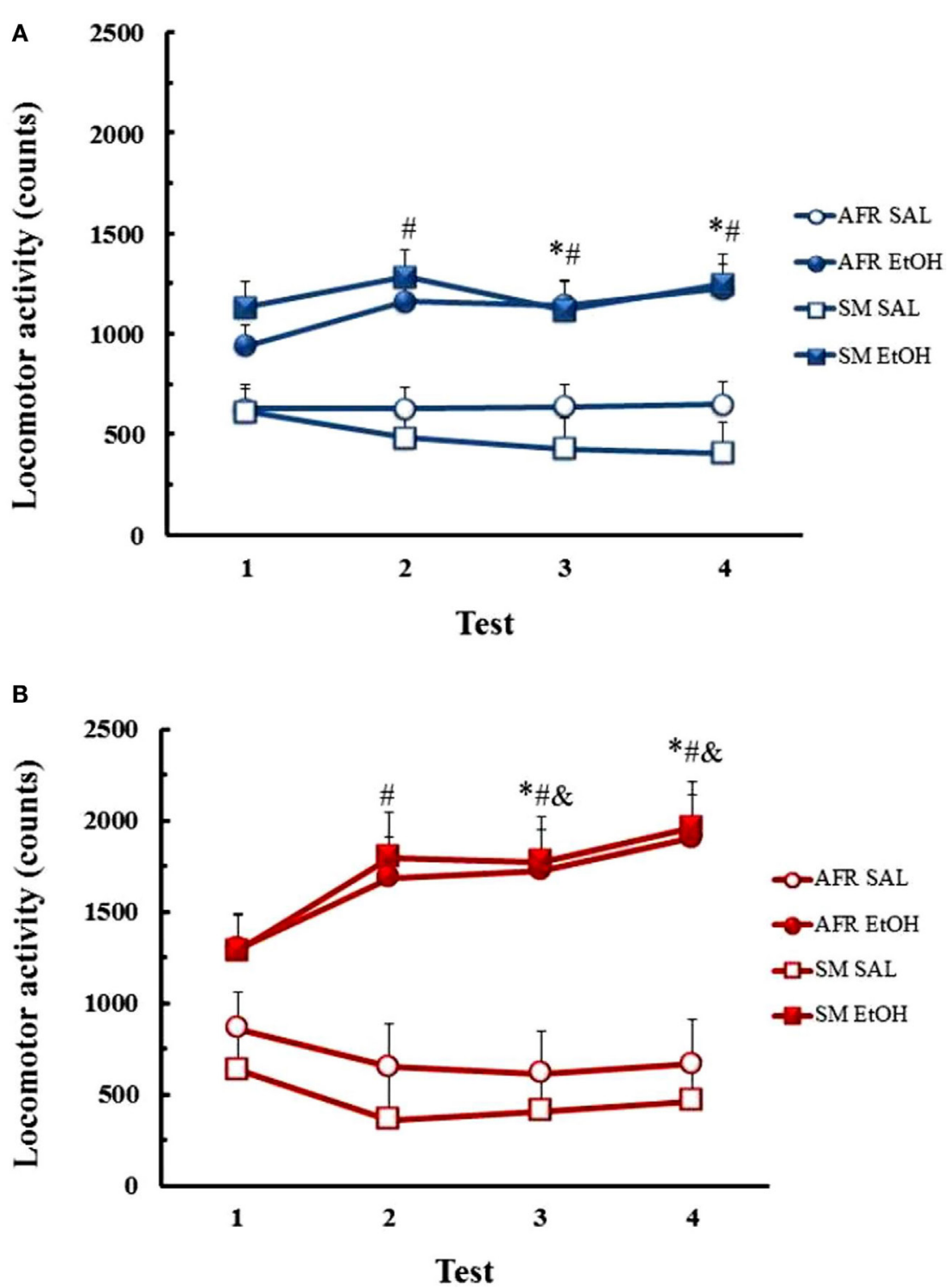

FIGURE 2 | Locomotor activity counts (mean \pm SEM) throughout the course of saline (SAL) or ethanol (EtOH) chronic treatment in AFR and LMS male (A) and female mice (B). Number of animals/group for each condition (sex, group, treatment) was 10-13. * - Different from saline-treated groups; \#- different from day $1 ; \&$ - different from day 7 .

effects (AFR vs. LMS). Analysis of the interaction showed that the locomotor activity of EtOH-treated mice was higher on days 7,14 , and 21 than on day 1 of treatment $(p<0.01)$ and on days 14 and 21 compared to day $7(p<0.01)$. EtOH-treated mice presented higher locomotor activity than SAL-treated mice on days 7,14 , and 21 of treatment $(p<0.01)$.

\section{Expression of Behavioral Sensitization} Males

Three-way ANOVA revealed main effects of pretreatment $\left[F_{(1,44)}=5.6872, p<0.03\right]$ and challenge $\left[F_{(3,132)}=19.841\right.$, $p<0.00001]$ and an interaction between these factors $\left[F_{(3,132)}=12.395, p<0.00001\right]$, with no group effect (Figure 3 ).
Post hoc analysis of the interaction showed that mice with a history of EtOH treatment displayed higher locomotor activity than SAL-pretreated counterparts in the SAL/EtOH challenge $(p<0.0005)$. Such differences were no longer observed during the NTX2/EtOH and NTX4/EtOH challenges, suggesting that EtOH-induced expression of sensitization was prevented by NTX. Moreover, in mice with a previous history of EtOH treatment, locomotor response to EtOH was the highest during the $\mathrm{SAL} / \mathrm{EtOH}$ challenge, with significant reductions when NTX was administered with EtOH (NTX2/EtOH and NTX4/EtOH challenges, $p$ 's < 0.005). In SAL-pretreated male mice, no changes in locomotor response were observed with any of the drug challenges, relative to the SAL/SAL challenge. 


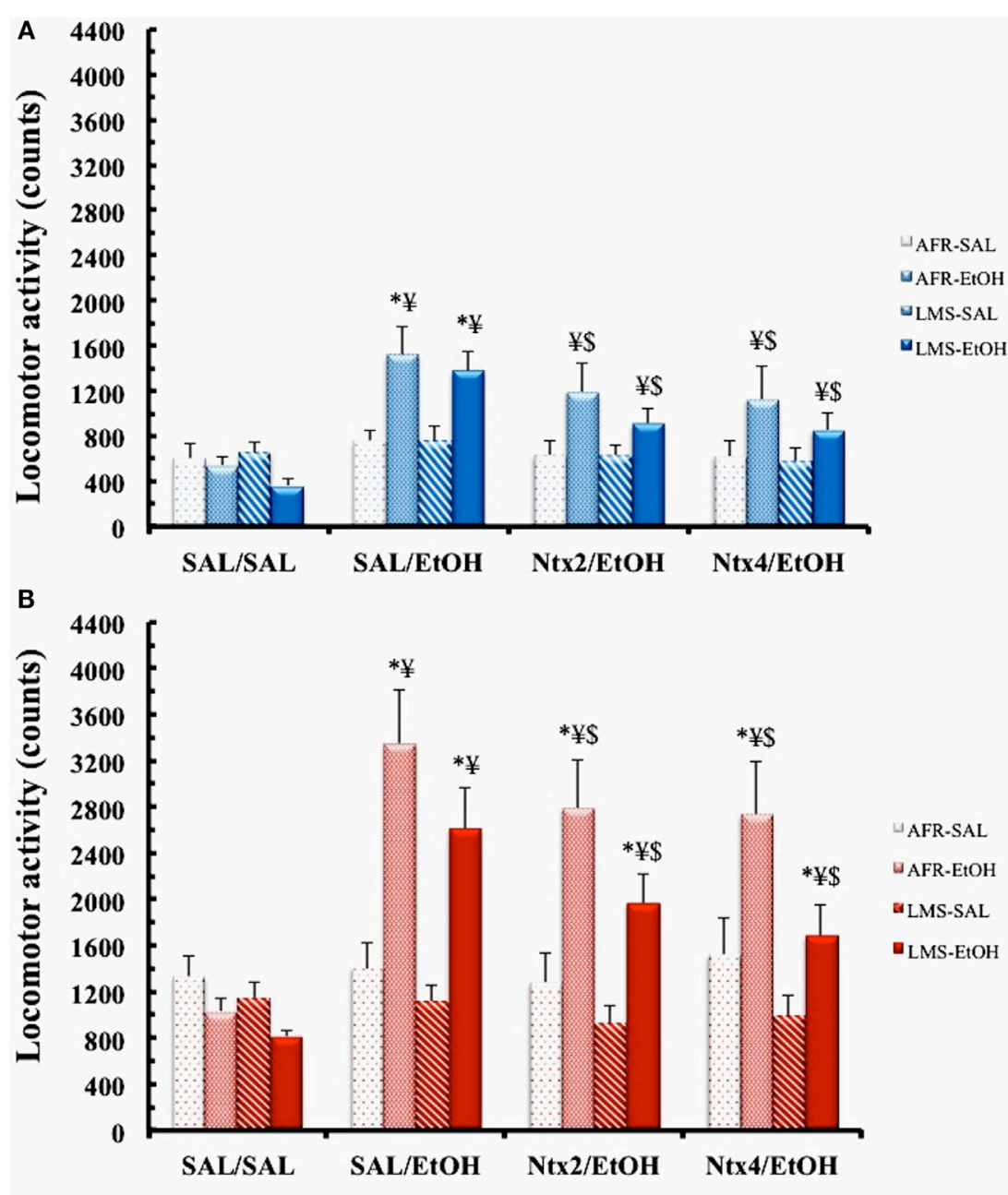

Challenge

FIGURE 3 | Locomotor activity counts (mean \pm SEM) of saline (SAL)- or ethanol (EtOH)-pretreated AFR and LMS males (A) or females (B) in the challenges SAL/SAL, SAL/EtOH, naltrexone $2.0 \mathrm{mg} / \mathbf{k g}$ - NTX2/EtOH, and naltrexone $4.0 \mathrm{mg} / \mathbf{k g}-\mathbf{N T X} 4 / \mathrm{EtOH}$. EtOH dose was $2.2 \mathrm{~g} / \mathrm{kg}$ (i.p.). Number of animals/group for each condition (sex, group, treatment) was 10-13. * - different from SAL-treated groups; $¥$ - different from SAL/SAL challenge, $\$$ - different from SAL/EtOH challenge.

\section{Females}

A three-way ANOVA showed main effects of group $\left[F_{(1,45)}=\right.$ $4.303 ; p<0.05]$, pretreatment $\left[F_{(1,45)}=12.983 ; p<0.001\right]$, and challenge $\left[F_{(3,135)}=22.48 ; p<0.00001\right]$ and an interaction between these two latter factors $\left[F_{(3,135)}=23.14 ; p<0.00001\right]$. Newman-Keuls analysis of the overall group effect showed that LMS animals exhibited lower locomotor activity than AFR mice $(p<0.03)$. Analysis of the pretreatment $\times$ challenge interaction revealed that mice with a history of EtOH preexposure displayed higher locomotor activity than SALpretreated ones in the SAL/ETOH $(p<0.0005)$, NTX2/EtOH $(p<0.001)$, and NTX4/EtOH $(p<0.005)$ challenges. However, the sensitized response to $\mathrm{EtOH}$ was significantly attenuated by co-treatment with both doses of NTX (NTX2 or NTX4; $p$ 's $<0.005)$. In mice pretreated with SAL, no changes in locomotor behavior were induced by challenges with $\mathrm{EtOH}$ or NTX/EtOH coadministration.

\section{DISCUSSION}

The results of the present study showed that the non-selective opioid antagonist, NTX, blocked the expression of behavioral sensitization to $\mathrm{EtOH}$ in male mice, and attenuated this phenomenon in females, regardless of the neonatal manipulation. Moreover, maternal separation had no impact on either the development or the expression of EtOH sensitization. Both males and females showed significant augmentation of locomotor responses to EtOH during the 21-day treatment (development of sensitization) and maintained a sensitized stimulant response when challenged with $\mathrm{EtOH}$ during the expression tests. 
In previous studies from our group, repeated $\mathrm{EtOH}$ administration induced behavioral sensitization in mice (36-39). Although an initial study reported that LMS could accelerate the development of EtOH sensitization in female, but not male mice (27), this was not confirmed using a more robust, 21-day treatment protocol (39), as replicated in our current findings. Thus, the facilitatory effects of LMS on EtOH sensitization seem to only emerge with weaker sensitizing regimens (e.g., $5 \mathrm{EtOH}$ injections), and in females. However, EtOH-induced corticosterone responses were higher in chronically EtOH-treated LMS males than in EtOH-treated controls, with no changes observed in females (39). Such changes in corticosterone response to chronic EtOH were not observed when mice received fewer EtOH treatments (27). Thus, LMS may modulate different behavioral and physiological/hormonal responses to EtOH in a sex-dependent and exposure-dependent manner.

A role for opioid receptor modulation of acute EtOH locomotor stimulation was reported by studies showing that opioid antagonists reduced $\mathrm{EtOH}$-induced hyperactivity in mice (30-32), despite controversial findings (40). Coadministration of non-specific opioid receptor antagonists, such as NTX and naloxone, blocked the development of EtOH locomotor sensitization $(32,33)$. However, in mice previously sensitized to EtOH, NTX and naloxone failed to prevent the expression of EtOH sensitization $(32,34)$. In contrast, the present study showed important effects of NTX preventing and/or attenuating the expression of $\mathrm{EtOH}$ sensitization in males and females, while not inducing locomotor effects in animals with no previous EtOH history. This finding contrasts with Abrahao and colleagues, who reported no effect of NTX on the expression of EtOH sensitization (34). However, the NTX dose was considerably lower in that study, $0.1 \mathrm{mg} / \mathrm{kg}$ (34). Indeed, in a pilot study using male mice with no neonatal manipulation, we observed significant reduction of EtOH sensitization using NTX doses of $1 \mathrm{mg} / \mathrm{kg}$ and higher, but not with a $0.5 \mathrm{mg} / \mathrm{kg}$ dose (data not shown). The dose range necessary to block the expression of sensitization in male mice in our study $(2 \mathrm{mg} / \mathrm{kg})$ was similar to that required for preventing the development of $\mathrm{EtOH}$ sensitization as reported by Pastor and Aragon [1 or $2 \mathrm{mg} / \mathrm{kg}$ (33)].

Despite acting as non-selective antagonists at opioid receptors, both NTX and naloxone have preferential effects on $\mu$-receptors, rather than on $\delta$-receptors $(30,33,41)$. Thus, our findings support an additional role for $\mu$-receptors in the modulation of the expression of EtOH sensitization, besides mediating the development of EtOH sensitization (32, 33). Indeed, Pastor and Aragon showed that both NTX and a selective antagonist at $\mu$-receptors, CTOP, blocked the development of EtOH sensitization, which was not affected by a delta-receptor antagonist, naltrindole. Moreover, the facilitation of EtOH sensitization after a period of $\mathrm{EtOH}$ consumption was absent in a recombinant line of mice with reduced expression and function of $\mu$-receptors, CXBK mice (42). Altogether, these studies point to $\mu$-receptors as the critical target for NTX's effects on EtOH sensitization. A putative mechanism for NTX effects relies on the modulation of dopamine neurons projecting from the ventral tegmental area (VTA) to the nucleus accumbens (NAcc), a pathway involved in drug-stimulation, sensitization, and reward [e.g., Ref. $(18,19$,
43)]. Opioid receptors, including $\mu$-receptors, are located in both regions, where they modulate dopamine output directly (in the NAcc) or indirectly (via GABA interneurons in VTA) $(18,19)$. Indeed, local administration of NTX into the VTA or the NAcc inhibits acute EtOH-induced stimulation in mice (29). Thus, it would be expected that $\mu$-receptor blockade in either or both brain regions could participate in the prevention/attenuation of the expression of EtOH sensitization reported in this study.

Remarkably, while NTX treatment blocked the expression of EtOH sensitization in males, in females there was only an attenuation of EtOH-sensitized response. In males, NTX administration, at both doses, blocked the expression of behavioral sensitization, since there were no longer differences in locomotor behavior between SAL- and EtOH-pretreated mice in the challenges. In females, both doses of NTX reduced, but failed to completely prevent a sensitized response to $\mathrm{EtOH}$, suggesting a sexual dimorphism in the behavioral response to this opioid antagonist. In agreement with these findings, several studies report on sexual differences in response to opioidergic drugs. For example, NTX treatment is less effective in women than in men $(44,45)$, men are more vulnerable to opioid addiction than women (46), and males are more responsive to analgesic drugs than females, in several species (47). In a recent study carried out with rats bred for increased preference for ethanol, a low acute dose of NTX was effective to block spontaneous ethanol intake in male, but not in female, rats (48). NTX is also capable to reduce the intake of a highly palatable sucrose solution only in LMS males, but not in females (49). Sex steroid hormones appear to regulate the density of opioid receptors in the hypothalamus, with increased density of $\mu$-opioid receptors during proestrus, and changes in $\mu$ receptor density in other limbic regions induced by hormone replacement in ovariectomized rats (50). Interestingly, full agonists of $\mu$ receptors in males act as partial agonists in female rats and primates (51), suggesting smaller affinity for these receptors in females. Thus, the reduced efficiency of NTX in blocking the expression of EtOH sensitization in female mice may be due to a smaller affinity/efficacy in $\mu$-opioid receptor signaling in females.

In the present study, the only effect of maternal separation was seen in female mice, which displayed lower locomotor activity than their AFR counterparts during the expression, but not during the development of behavioral sensitization. Few studies had compared the induction and/or expression of behavioral sensitization between maternally separated male and female animals, with contradictory results. LMS has been reported to increase induction of behavioral sensitization to cocaine in male and female mice, but only males exhibited increased expression to a cocaine challenge (26). As mentioned in the Introduction, development of EtOH sensitization was facilitated in LMS female, but not in male mice, using a weaker sensitizing protocol (27), but not with a stronger one, with more prolonged EtOH treatment (39). Amphetamine sensitization was also not modified by maternal separation in rats $(52,53)$. However, LMS reduces the response rate for intracranial selfstimulation in female, but not in male rats (54).

In conclusion, NTX blocked the expression of EtOH-induced behavioral sensitization in male mice, while significantly attenuating EtOH sensitization in females, with no effects of neonatal 
manipulation. The only detectable effect of maternal separation was an overall reduced locomotor behavior of female mice during the expression tests for $\mathrm{EtOH}$ sensitization.

\section{AUTHOR CONTRIBUTIONS}

SK planned and performed the experiments described, analyzed the results, and wrote the original version of the manuscript. SK, IQ, and DS participated in defining experimental design, data analysis, and interpretation of results, as well as revising and writing the final version of the manuscript.

\section{REFERENCES}

1. Rosenfeld P, Gutierrez YA, Martin AM, Mallett HA, Alleva E, Levine S. Maternal regulation of the adrenocortical response in preweanling rats. Physiol Behav (1991) 50(4):661-71. doi:10.1016/0031-9384(91)90001-5

2. Rosenfeld P, Suchecki D, Levine S. Multifactorial regulation of the hypothalamic-pituitary-adrenal axis during development. Neurosci Biobehav Rev (1992) 16(4):553-68. doi:10.1016/S0149-7634(05)80196-4

3. Rosenfeld P, Ekstrand J, Olson E, Suchecki D, Levine S. Maternal regulation of adrenocortical activity in the infant rat: effects of feeding. Dev Psychobiol (1993) 26(5):261-77. doi:10.1002/dev.420260504

4. Suchecki D, Mozaffarian D, Gross G, Rosenfeld P, Levine S. Effects of maternal deprivation on the ACTH stress response in the infant rat. Neuroendocrinology (1993) 57(2):204-12. doi:10.1159/000126361

5. Suchecki D, Nelson DY, Van Oers H, Levine S. Activation and inhibition of the hypothalamic-pituitary-adrenal axis of the neonatal rat: effects of maternal deprivation. Psychoneuroendocrinology (1995) 20(2):169-82. doi:10.1016/0306-4530(94)00051-B

6. Levine S, Huchton DM, Wiener SG, Rosenfeld P. Time course of the effect of maternal deprivation on the hypothalamic-pituitary-adrenal axis in the infant rat. Dev Psychobiol (1991) 24(8):547-58. doi:10.1002/dev.420240803

7. Faturi CB, Tiba PA, Kawakami SE, Catallani B, Kerstens M, Suchecki D. Disruptions of the mother-infant relationship and stress-related behaviours: altered corticosterone secretion does not explain everything. Neurosci Biobehav Rev (2010) 34(6):821-34. doi:10.1016/j.neubiorev.2009.09.002

8. Schmidt M, Enthoven L, van Woezik JH, Levine S, de Kloet ER, Oitzl MS. The dynamics of the hypothalamic-pituitary-adrenal axis during maternal deprivation. J Neuroendocrinol (2004) 16(1):52-7. doi:10.1111/j.1365-2826. 2004.01123.x

9. Sánchez MM, Ladd CO, Plotsky PM. Early adverse experience as a developmental risk factor for later psychopathology: evidence from rodent and primate models. Dev Psychopathol (2001) 13(3):419-49. doi:10.1017/ S0954579401003029

10. Moffett MC, Vicentic A, Kozel M, Plotsky P, Francis DD, Kuhar MJ. Maternal separation alters drug intake patterns in adulthood in rats. Biochem Pharmacol (2007) 73(3):321-30. doi:10.1016/j.bcp.2006.08.003

11. Nylander I, Roman E. Neuropeptides as mediators of the early-life impact on the brain; implications for alcohol use disorders. Front Mol Neurosci (2012) 5:77. doi:10.3389/fnmol.2012.00077

12. Gustafsson L, Oreland S, Hoffmann P, Nylander I. The impact of postnatal environment on opioid peptides in young and adult male Wistar rats. Neuropeptides (2008) 42(2):177-91. doi:10.1016/j.npep.2007.10.006

13. Gustafsson L, Ploj K, Nylander I. Effects of maternal separation on voluntary ethanol intake and brain peptide systems in female Wistar rats. Pharmacol Biochem Behav (2005) 81(3):506-16. doi:10.1016/j.pbb.2005.03.016

14. Marmendal M, Roman E, Eriksson CJ, Nylander I, Fahlke C. Maternal separation alters maternal care, but has minor effects on behavior and brain opioid peptides in adult offspring. Dev Psychobiol (2004) 45(3):140-52. doi:10.1002/ dev.20027

15. Ploj K, Roman E, Nylander I. Long-term effects of short and long periods of maternal separation on brain opioid peptide levels in male Wistar rats. Neuropeptides (2003) 37(3):149-56. doi:10.1016/S0143-4179(03)00043-X

16. Kalinichev M, Easterling KW, Holtzman SG. Early neonatal experience of Long-Evans rats results in long-lasting changes in reactivity to a

\section{ACKNOWLEDGMENTS}

The authors would like to express their gratitude to Marcus Vinícius Bunscheit for technical assistance in this study. This work was supported by Associação Fundo de Incentivo à Pesquisa (AFIP) and Fundação de Amparo à Pesquisa de São Paulo (FAPESP). SK was the recipient of a fellowship from FAPESP (Process \# 2007/01287-0) and DS is a research fellow from Conselho Nacional Científico e Tecnológico (CNPq). Payment for this publication was made possible by FAPESP (grant \#2015/2636-4).

novel environment and morphine-induced sensitization and tolerance. Neuropsychopharmacology (2002) 27(4):518-33.

17. Akil H, Owens C, Gutstein H, Taylor L, Curran E, Watson S. Endogenous opioids: overview and current issues. Drug Alcohol Depend (1998) 51(1-2): 127-40. doi:10.1016/S0376-8716(98)00071-4

18. Méndez M, Morales-Mulia M. Role of mu and delta opioid receptors in alcohol drinking behaviour. Curr Drug Abuse Rev (2008) 1(2):239-52. doi:10.2174/1 874473710801020239

19. Spanagel R, Herz A, Shippenberg TS. Opposing tonically active endogenous opioid systems modulate the mesolimbic dopaminergic pathway. Proc Natl Acad Sci U S A (1992) 89(6):2046-50. doi:10.1073/pnas.89.6.2046

20. Vazquez V, Penit-Soria J, Durand C, Besson MJ, Giros B, Dauge V. Maternal deprivation increases vulnerability to morphine dependence and disturbs the enkephalinergic system in adulthood. J Neurosci (2005) 25(18):4453-62. doi:10.1523/JNEUROSCI.4807-04.2005

21. Huot RL, Thrivikraman KV, Meaney MJ, Plotsky PM. Development of adult ethanol preference and anxiety as a consequence of neonatal maternal separation in Long Evans rats and reversal with antidepressant treatment. Psychopharmacology (Berl) (2001) 158(4):366-73. doi:10.1007/s002130100701

22. Ploj K, Roman E, Nylander I. Long-term effects of maternal separation on ethanol intake and brain opioid and dopamine receptors in male Wistar rats. Neuroscience (2003) 121(3):787-99. doi:10.1016/S0306-4522(03) 00499-8

23. Roman E, Nylander I. The impact of emotional stress early in life on adult voluntary ethanol intake-results of maternal separation in rats. Stress (2005) 8(3):157-74. doi:10.1080/10253890500188666

24. Cruz FC, Quadros IM, Planeta Cda S, Miczek KA. Maternal separation stress in male mice: long-term increases in alcohol intake. Psychopharmacology (Berl) (2008) 201(3):459-68. doi:10.1007/s00213-008-1307-4

25. Roman E, Ploj K, Nylander I. Maternal separation has no effect on voluntary ethanol intake in female Wistar rats. Alcohol (2004) 33(1):31-9. doi:10.1016/ S0741-8329(04)00077-1

26. Kikusui T, Faccidomo S, Miczek KA. Repeated maternal separation: differences in cocaine-induced behavioral sensitization in adult male and female mice. Psychopharmacology (Berl) (2005) 178(2-3):202-10. doi:10.1007/ s00213-004-1989-1

27. Kawakami SE, Quadros IMH, Takahashi S, Suchecki D. Long maternal separation accelerates behavioural sensitization to ethanol in female, but not in male mice. Behav Brain Res (2007) 184(2):109-16. doi:10.1016/j.bbr.2007. 06.023

28. Camarini R, Pautassi RM, Méndez M, Quadros IM, Souza-Formigoni ML, Boerngen-Lacerda R. Behavioral and neurochemical studies in distinct animal models of ethanol's motivational effects. Curr Drug Abuse Rev (2010) 3(4):205-21. doi:10.2174/1874473711003040205

29. Font L, Luján M, Pastor R. Involvement of the endogenous opioid system in the psychopharmacological actions of ethanol: the role of acetaldehyde. Front Behav Neurosci (2013) 7:93. doi:10.3389/fnbeh.2013.00093

30. Pastor R, Sanchis-Segura C, Aragon CM. Effect of selective antagonism of $\mathrm{mu}(1)-, \mathrm{mu}(1 / 2)-, \mathrm{mu}(3)-$, and delta-opioid receptors on the locomotor-stimulating actions of ethanol. Drug Alcohol Depend (2005) 78(3):289-95. doi:10.1016/j.drugalcdep.2004.11.007

31. Sanchis-Segura C, Pastor R, Aragon CM. Opposite effects of acute versus chronic naltrexone administration on ethanol-induced locomotion. Behav Brain Res (2004) 153(1):61-7. doi:10.1016/j.bbr.2003.11.003 
32. Camarini R, Nogueira Pires ML, Calil HM. Involvement of the opioid system in the development and expression of sensitization to the locomotor-activating effect of ethanol. Int J Neuropsychopharmacol (2000) 3(4):303-9. doi:10.1017/ S146114570000211X

33. Pastor R, Aragon CM. The role of opioid receptor subtypes in the development of behavioral sensitization to ethanol. Neuropsychopharmacology (2006) 31(7):1489-99. doi:10.1038/sj.npp.1300928

34. Abrahao KP, Quadros IM, Souza-Formigoni ML. Morphine attenuates the expression of sensitization to ethanol, but opioid antagonists do not. Neuroscience (2008) 156(4):857-64. doi:10.1016/j.neuroscience.2008.08.012

35. Oswald LM, Wand GS. Opioids and alcoholism. Physiol Behav (2004) 81(2):339-58. doi:10.1016/j.physbeh.2004.02.008

36. Quadros IM, Souza-Formigoni ML, Fornari RV, Nobrega JN, Oliveira MG. Is behavioral sensitization to ethanol associated with contextual conditioning in mice? Behav Pharmacol (2003) 14(2):129-36. doi:10.1097/0000 8877-200303000-00004

37. Takahashi S, Fornari RV, Quadros IM, Oliveira MG, Souza-Formigoni ML. Does scopolamine block the development of ethanol-induced behavioral sensitization? Alcohol Clin Exp Res (2007) 31(9):1482-9. doi:10.1111/j.15300277.2007.00446.x

38. Quadros IM, Nobrega JN, Hipolide DC, de Lucca EM, Souza-Formigoni ML. Differential propensity to ethanol sensitization is not associated with altered binding to D1 receptors or dopamine transporters in mouse brain. Addict Biol (2002) 7(3):291-9. doi:10.1080/13556210220139505

39. Kawakami SE, Quadros IM, Machado RB, Suchecki D. Sex-dependent effects of maternal separation on plasma corticosterone and brain monoamines in response to chronic ethanol administration. Neuroscience (2013) 253C:55-66. doi:10.1016/j.neuroscience.2013.08.031

40. Holstein SE, Pastor R, Meyer PJ, Phillips TJ. Naloxone does not attenuate the locomotor effects of ethanol in FAST, SLOW, or two heterogeneous stocks of mice. Psychopharmacology (Berl) (2005) 182(2):277-89. doi:10.1007/ s00213-005-0066-8

41. Williams JT, Christie MJ, Manzoni O. Cellular and synaptic adaptations mediating opioid dependence. Physiol Rev (2001) 81(1):299-343.

42. Tarragón E, Baliño P, Aragon CM, Pastor R. Ethanol drinking-in-the-dark facilitates behavioral sensitization to ethanol in C57BL/6J, BALB/cByJ, but not in mu-opioid receptor deficient CXBK mice. Pharmacol Biochem Behav (2012) 101(1):14-23. doi:10.1016/j.pbb.2011.11.014

43. Nestler EJ. Is there a common molecular pathway for addiction? Nat Neurosci (2005) 8(11):1445-9. doi:10.1038/nn1578

44. Fillingim RB, Gear RW. Sex differences in opioid analgesia: clinical and experimental findings. Eur JPain (2004) 8(5):413-25. doi:10.1016/j. ejpain.2004.01.007

45. Garbutt JC, Kranzler HR, O’Malley SS, Gastfriend DR, Pettinati HM, Silverman BL, et al. Efficacy and tolerability of long-acting injectable naltrexone for alcohol dependence: a randomized controlled trial. JAMA (2005) 293(13):1617-25. doi:10.1001/jama.293.13.1617

46. Lee CW, Ho IK. Sex differences in opioid analgesia and addiction: interactions among opioid receptors and estrogen receptors. Mol Pain (2013) 9:45. doi:10.1186/1744-8069-9-45

47. Bodnar RJ, Kest B. Sex differences in opioid analgesia, hyperalgesia, tolerance and withdrawal: central mechanisms of action and roles of gonadal hormones. Horm Behav (2010) 58(1):72-81. doi:10.1016/j.yhbeh.2009. 09.012

48. Moore CF, Lynch WJ. Alcohol preferring (P) rats as a model for examining sex differences in alcohol use disorder and its treatment. Pharmacol Biochem Behav (2015) 132:1-9. doi:10.1016/j.pbb.2015.02.014

49. Michaels CC, Holtzman SG. Enhanced sensitivity to naltrexone-induced drinking suppression of fluid intake and sucrose consumption in maternally separated rats. Pharmacol Biochem Behav (2007) 86(4):784-96. doi:10.1016/j. pbb.2007.03.007

50. Piva F, Limonta P, Dondi D, Pimpinelli F, Martini L, Maggi R. Effects of steroids on the brain opioid system. J Steroid Biochem Mol Biol (1995) 53(1-6):343-8. doi:10.1016/0960-0760(95)00072-8

51. Barrett AC. Low efficacy opioids: implications for sex differences in opioid antinociception. Exp Clin Psychopharmacol (2006) 14(1):1-11. doi:10.1037/1064-1297.14.1.1

52. Weiss IC, Domeney AM, Heidbreder CA, Moreau JL, Feldon J. Early social isolation, but not maternal separation, affects behavioral sensitization to amphetamine in male and female adult rats. Pharmacol Biochem Behav (2001) 70(2-3):397-409. doi:10.1016/S0091-3057(01)00626-8

53. Muhammad A, Kolb B. Maternal separation altered behavior and neuronal spine density without influencing amphetamine sensitization. Behav Brain Res (2011) 223(1):7-16. doi:10.1016/j.bbr.2011.04.015

54. Michaels CC, Easterling KW, Holtzman SG. Maternal separation alters ICSS responding in adult male and female rats, but morphine and naltrexone have little affect on that behavior. Brain Res Bull (2007) 73(4-6):310-8. doi:10.1016/j.brainresbull.2007.04.008

Conflict of Interest Statement: The authors declare that the research was conducted in the absence of any commercial or financial relationships that could be construed as a potential conflict of interest.

Copyright (C) 2016 Kawakami, Quadros and Suchecki. This is an open-access article distributed under the terms of the Creative Commons Attribution License (CC BY). The use, distribution or reproduction in other forums is permitted, provided the original author(s) or licensor are credited and that the original publication in this journal is cited, in accordance with accepted academic practice. No use, distribution or reproduction is permitted which does not comply with these terms. 